\title{
LIFE CYCLE ASSESSMENT OF THE STRAW MUSHROOM PRODUCTION
}

\author{
USUBHARATANA, P. - PHUNGRASSAMI, H. \\ Excellence Center of EcoEnergy, Chemical Engineering Department, Faculty of Engineering, \\ Thammasat University, Thailand. \\ (phone: +66-2-564-3001; fax: +66-2-564-3010) \\ ${ }^{*}$ Corresponding author \\ e-mail:pharnpon@engr.tu.ac.th \\ (Received $5^{\text {th }}$ Jun 2015; accepted $20^{\text {th }}$ Dec 2015)
}

\begin{abstract}
The life cycle assessment of a product (LCA) is a tool to calculate the quantity of environmental emissions from each production unit throughout the whole life cycle of a specific product starting from raw material extraction, manufacturing, use and distribution to the final disposal. This tool becomes increasingly more necessary to consumers as information pertaining to environmental impacts which partially supports their purchasing decisions in Thailand. Therefore, the objective of this study is to analyze the environmental impacts of SMEs straw mushroom production with three different formulas including the soybean hull formula, rapeseed hull formula and the cassava peel formula. The functional unit was set at $1 \mathrm{~kg}$ of the straw mushroom at the farm gate. The inventory data was collected from a farm in Nakornsawan province, Thailand. The environmental impacts were dominated by global warming, eutrophication and acidification. Results were compared with environmental impacts of a straw mushroom production by using the rapeseed hull formula and the cassava peel formula with a soybean hull as the conventional method. Results indicated that the straw mushroom production with a cassava peel had the lowest environmental impacts. The comparison in terms of global warming impact of three formulas were $1.6 \mathrm{kgCO}_{2} \mathrm{e}$ for the soybean hull formula, $5.4 \mathrm{kgCO}_{2} \mathrm{e}$ for the rapeseed hull formula and 0.8 $\mathrm{kgCO}_{2} \mathrm{e}$ for the cassava peel formula. The acidification impact of the soybean hull, cassava peel and the rapeseed hull were revealed at $13.5 \mathrm{gSO}_{2} \mathrm{e}, 8.3 \mathrm{gSO}_{2} \mathrm{e}$ and $23.9 \mathrm{gSO}_{2} \mathrm{e}$, respectively. The eutrophication impact of the soybean hull, cassava peel and the rapeseed hull were $10.0 \mathrm{gPO}_{4}^{3-} \mathrm{e}, 1.9 \mathrm{gPO}_{4}^{3-\mathrm{e}}$ and 42.5 $\mathrm{gPO}_{4}{ }^{3-} \mathrm{e}$, respectively. Uncertainty analysis of production yield, fungi yield, types of cotton production and types of plastic used were evaluated. The result showed that the organic farming of cotton production could reduce environmental impacts of straw mushroom production.
\end{abstract}

Keywords: Volvariella volvacea, global warming, eutrophication, acidification, life cycle impact assessment

\section{Introduction}

The mushroom is the fruiting body of a macro-fungi (Chang and Milles, 1991). The world production of mushrooms were 7.96 million tons in 2012 (FAOSTAT, 2012). China, as the largest mushroom producing country in the world, produced 5.15 million tons alone. For Thailand, mushroom production was 6,820 tons in 2012 (FAOSTAT, 2012). In 2012, agricultural products accounted for $12.3 \%$ of Thailand's gross domestic product (GDP) (OAE, 2013)

The straw mushroom is a kind of mushrooms that is preferred by most consumers because of its aroma and taste (Tharun, 1993). Straw mushrooms, scientifically known as Volvariella volvacea, is a type of mushroom abundantly found throughout Asia. Paddy straw is the most common substrate for this mushroom. Nowadays, it is popular among consumers because of its distinct flavor, pleasant taste, higher protein content and shorter cropping duration (Rajapakse, 2011). Straw mushrooms can be used as an ingredient in a vast variety of Thai recipes, such as stir-fried pork with oyster sauce, spicy soup with prawn and lemon grass or chicken Tom Yum. 
New trends in the environment, economy and society have been growing and is a concern when dealing with current non-sustainable developments. These factors have led to an increased interest in the life cycle assessment (LCA) as it is a tool used to evaluate the environmental impacts of products, services or processes. Food, one of the primary needs of human beings, creates an environmental impacts in each phase of its life cycle. In Thailand, there has been a concern in the food industrial sector regarding the significant impact to global warming.

Several researchers have studied many aspects about the straw mushroom such as the techniques for its cultivation for which cotton waste and paddy straw are used (Rajapakse, 2011). The cultivation of the straw mushroom has been tested with various agricultural by-products such as banana leaves, sawdust, rice bran, wheat bran, sugarcane bagasse, wheat and rice straw. However, straw alone is not sufficient as a composting material as it contains little in the quantity of nutrients (Anon, 1983). There are a few publications related to the LCA calculation of mushrooms. The LCA of the sajor-caju mushroom was determined and evaluated from three farm sizes (Ueawiwatsakul et al., 2014). Gunady et al. (2012) determined the LCA from strawberries, lettuces and button mushrooms in Western Australia. However, none of these studies have been specified in the LCA of straw mushrooms or even in Thailand.

Therefore, the main objective in this study was to analyze three environmental impacts including the potential of global warming, acidification and eutrophication. In addition, the sub-objectives were 1) to compare three different cultivation formulas; soybean hull, cassava peel and rapeseed hull formulas, 2) to identify emission hotspots with the highest amount of environmental impacts and 3) to evaluate the uncertainties of core factors related to the cultivation process.

\section{Materials and Methods}

Methods of commercial mushroom cultivation generally involve inoculating beds of composts with mushroom spawn. Such compost is rich in nutrients and capable of supporting the mushroom fruiting stage (Romaine and Marlowe, 1995). The addition of protein-rich, lipid-rich supplements such as soybean meal to the compost has become a widespread practice in the commercial cultivation of the button mushroom (Romaine and Marlowe, 1995).

According to the guidelines in ISO14040 (2006), LCA consists of four phases namely: 1) goal and scope definition that includes the functional unit and system boundary 2) inventory analysis of inputs and outputs of the selected boundary 3) environmental impact assessment classifying the collected data into impact categories and 4) interpretation which leads to the conclusions and verifications.

\section{Goal and scope definition}

The main purpose of this study was to analyze three environmental impacts in terms of global warming, eutrophication and acidification of straw mushroom production with different formulas. The LCA was utilized as the tool to analyze these impacts in this study. The classification and characterization method of CML based line 2001 was also applied. Three scenarios (case 1 to case 3 ) were considered depending on the main raw materials used for cultivation process. A soybean hull, cassava peel and rapeseed hull were used as the raw materials for case 1, case 2 and case 3, respectively. The sub objectives were 1) to compare three different cultivation systems; soybean hull, cassava 
peel and rapeseed hull formulas 2) to identify the hotspots at which the inputs emit the highest amount of environmental impacts and 3) to evaluate uncertainties of core factors related to the cultivation process. Based on this study, the research questions can be summarized as 1) What are the environmental impacts of the straw mushroom in each scenario? 2) What are the main hotspots associated with straw mushroom production? 3) What are the important factors related to the uncertainty of the results of this study?

\section{System boundary}

The straw mushroom was cultivated on shelves of grow bags in plant houses with rows of shelves inside. These houses are tolerant to subsequent, severe heat treatment during on-sight pasteurization (Kwon and Thatithatgoon, 2004). The cultivation phase in this study began with marinating cotton and cow manure for one night. In addition to that, soaked rice bran, lime, gypsum, urea fertilizer and compressed rice straw together in water for one night was also used. Subsequently, all were placed in a row and materials steamed at 80 degree Celsius for three hours as per the pasteurization procedure. Lastly, the mushroom spores were spread in grow bags under the conditioned ambient at temperatures of 32-38 degree Celsius for twenty days until time of harvest.

The selected farm is located in Nakornsawan province in the central part of Thailand. This system boundary included raw materials used in this straw mushroom production such as soybean hull, cassava peel, rapeseed hull, urea, rice straw as well as other materials, and the production of the straw mushroom in the so called "cradle-to-farm gate". The pre-farm stage included emissions from fertilizer production, chemical production, electricity, gypsum production, lime production, cotton production, wood chip and plastic bag. The on-farm stage included fertilizer use, electricity consumption, chemical uses as well as both direct and indirect $\mathrm{N}_{2} \mathrm{O}$ emissions from $\mathrm{N}$-fertilizer applications. However, the production of capital goods from the system boundary and transportation of all raw materials were excluded. In addition, the product system excluded solid waste from cultivation.

\section{Functional unit}

The activity data of both input and output, and the environmental impact are related to the functional unit. The functional unit is defined as a quantitative reference to which inputs and outputs are related to the selected boundary. It is one of the keys in the LCA, facilitating the comparison of alternative products and services (ISO14040, 2006). In this study, the functional unit of this study was defined as $1 \mathrm{~kg}$ of straw mushroom produced in Thailand.

\section{Results and discussion}

\section{Life cycle inventory}

In the inventory phase, all data required to analyze the environmental impacts associated with the functional unit were gathered. In this study, data was derived from various sources. Primary data was the first option in this step. A one year period of activity data on straw mushroom production was collected from a farm located in the central part of Thailand. Different cultivation methods were identified by using a life cycle inventory (LCI). For the assembly of the inventory, the foreground system was 
considered based on the primary data from actual field operations during the cultivation process. However, the data associated with the effects as a result of the inputs such as fertilizer production, electricity, plastic production and chemicals production were obtained from a secondary data source such as the Thailand National LCI database and other literature sources.

Thailand possesses very suitable attributes for mushroom cultivation as there is a large number of left-over material and agricultural by-products from plants and animals that can be used for growing mushrooms (Thongnaitham, 2012). A variety of waste material used for general cultivation of straw mushrooms includes paddy straw, water hyacinth, oil palm bunch, banana leaves, saw dust, cotton or sugarcane bagasse. However, waste material used in this study included soybean hull, cassava peel and rapeseed hull and the average inventory with three formulas are shown in Table 1. Inventory values of material and energies used for producing $1 \mathrm{~kg}$ of straw mushroom. Gypsum and lime are used to adjust the $\mathrm{pH}$ and provide mushrooms with calcium and magnesium (Thongnaitham, 2012).

Table 1. Inventory activity data of $1 \mathrm{~kg}$ straw mushroom

\begin{tabular}{lccc}
\hline Inventory activity data & \multicolumn{3}{c}{ Value } \\
\cline { 2 - 4 } & Case 1 (soybean) & Case 2 (cassava) & Case 3 (rapeseed) \\
\hline Soybean hull $(\mathrm{kg})$ & 1.4969 & - & 3.2550 \\
Cassava peel $(\mathrm{kg})$ & - & 1.0396 & - \\
Rapeseed hull $(\mathrm{kg})$ & - & - & 2.3508 \\
Cow dung $(\mathrm{kg})$ & 0.0832 & 0.0578 & 0.1808 \\
Cotton $(\mathrm{kg})$ & 0.4990 & 0.3465 & 1.0850 \\
Rice bran $(\mathrm{kg})$ & 0.2495 & 0.1733 & 0.5425 \\
Lime $(\mathrm{kg})$ & 0.0125 & 0.0087 & 0.0271 \\
Gypsum $(\mathrm{kg})$ & 0.0166 & 0.0116 & 0.0362 \\
Urea $(\mathrm{kg})$ & 0.0042 & 0.0029 & 0.0090 \\
Straw $(\mathrm{kg})$ & 1.0811 & 0.7508 & - \\
Fungi spawn $(\mathrm{kg})$ & 0.3400 & 0.2300 & 0.7324 \\
Underground water (L) & 43.2432 & 30.0335 & 94.0325 \\
Wood chip $(\mathrm{kg})$ & 0.9979 & 0.6931 & 2.1700 \\
Plastic bag $(\mathrm{kg})$ & 0.0064 & 0.0064 & 0.0064 \\
Electricity $(\mathrm{kWh})$ & 0.0124 & 0.0086 & 0.0270 \\
\hline
\end{tabular}

\section{Emission factor}

The emission factors for material and fuel production, fuel combustion, electricity generation, direct and indirect emission due to synthetic and organic fertilizers are listed in Table 2. Emission factors assessed in this study were taken from the Thailand National LCI database and international database. If available, Thailand specific emission factors were also used. The emission factor of the electricity grid mix was calculated based on Thailand's National LCI database. Emission factors resulted from rice bran and straw production were estimated from the LCI of rice production and allocated by mass (Kasmaprapruet et al., 2009). The mushroom spore is generally referred to as a spawn (Oei, 2005). In this study spawn production involved raw materials such as cow manure and soybean hull. Based on the interviews, to produce one kilogram of spawn, $0.32 \mathrm{~kg}$ cow manure and $0.66 \mathrm{~kg}$ soybean hull were used. Moreover, in terms of wood chip and cassava peel, production inventory data was also estimated from the primary data collected from rubber tree farmers and the cassava 
industry respectively. In the case that no emission factors in Thailand were evident, international databases were then estimated from an ecoinvent database or other literatures. The direct $\mathrm{N}_{2} \mathrm{O}$ emission factor was estimated to be $1 \%$ of applied $\mathrm{N}$ fertilizer both synthetic and organic fertilizer (IPCC, 2006). To estimate the impacts of organic fertilizer used in the process, the composition of cow manure must be known. The composition of nitrogen $(\mathrm{N})$, phosphorous $(\mathrm{P})$ and potassium $(\mathrm{K})$ in cow manure are $0.57 \%, 0.15 \%$ and $1.22 \%$, respectively (Akhtar et al., 2013). The indirect $\mathrm{N}_{2} \mathrm{O}$ emission factor was assumed by calculating N-leaching and N-runoff (IPCC, 2006). Moreover, the $\mathrm{CO}_{2}$ emission due to urea fertilizer and lime were determined to be $20 \%$ of applied urea and 12\% of applied lime, respectively (IPCC, 2006).

Table 2. Emission factors for maternail productions including direct and indirect emissions

\begin{tabular}{|c|c|c|c|c|}
\hline \multirow[t]{2}{*}{ Material } & \multicolumn{3}{|c|}{ Emission factor } & \multirow[b]{2}{*}{ Source } \\
\hline & $\begin{array}{c}\text { GWP } \\
\left(\mathrm{kgCO}_{2} \mathrm{e} / \text { unit }\right)\end{array}$ & $\begin{array}{c}\mathrm{AP} \\
\left(\mathrm{kgSO}_{2} \mathrm{e} / \text { unit }\right)\end{array}$ & $\begin{array}{c}\text { EP } \\
\left(\mathrm{kgPO}_{4}{ }^{3-} \mathrm{e} / \text { unit }\right)\end{array}$ & \\
\hline Soybean hull & $2.69 \mathrm{E}-1$ & $3.78 \mathrm{E}-3$ & $2.89 \mathrm{E}-3$ & CML2001, Ecoinvent database \\
\hline Cassava peel & $8.41 \mathrm{E}-3$ & $2.69 \mathrm{E}-3$ & $2.40 \mathrm{E}-5$ & Field visited \\
\hline Rapeseed hull & $9.74 \mathrm{E}-1$ & $5.83 \mathrm{E}-3$ & $9.71 \mathrm{E}-4$ & Bernesson, 2004 \\
\hline Cow dung & $3.51 \mathrm{E}-2$ & $1.11 \mathrm{E}-3$ & $2.48 \mathrm{E}-4$ & $\begin{array}{l}\text { Calculated from manure } \\
\text { management (IPCC, 2006) }\end{array}$ \\
\hline Cotton & $1.33 \mathrm{E}+0$ & $1.16 \mathrm{E}-2$ & $2.89 \mathrm{E}-3$ & Murugesh and Selvadass, 2013 \\
\hline Rice bran & $1.05 \mathrm{E}-1$ & $1.86 \mathrm{E}-4$ & $2.18 \mathrm{E}-5$ & $\begin{array}{l}\text { Calculated from Kasmaprapruet } \\
\text { et al, } 2009\end{array}$ \\
\hline Lime & $1.92 \mathrm{E}-3$ & $3.38 \mathrm{E}-5$ & $7.79 \mathrm{E}-6$ & CML2001, Ecoinvent database \\
\hline Gypsum & $2.03 \mathrm{E}-3$ & $3.45 \mathrm{E}-5$ & $7.92 \mathrm{E}-6$ & CML2001, Ecoinvent database \\
\hline Urea & $5.93 \mathrm{E}+0$ & $1.62 \mathrm{E}-2$ & $2.91 \mathrm{E}-3$ & CML2001, Ecoinvent database \\
\hline Straw & $1.26 \mathrm{E}-1$ & $2.23 \mathrm{E}-4$ & $2.62 \mathrm{E}-5$ & $\begin{array}{l}\text { Calculated from Kasmaprapruet } \\
\text { et al, } 2009\end{array}$ \\
\hline Fungi spawn & $1.89 \mathrm{E}-1$ & $2.85 \mathrm{E}-3$ & $3.27 \mathrm{E}-3$ & Field visited \\
\hline Wood chip & $2.05 \mathrm{E}-1$ & $6.35 \mathrm{E}-4$ & $1.29 \mathrm{E}-4$ & Field visited \\
\hline Plastic bag & $1.92 \mathrm{E}+0$ & $6.57 \mathrm{E}-3$ & $5.16 \mathrm{E}-4$ & CML2001, Ecoinvent database \\
\hline Electricity & $6.09 \mathrm{E}-1$ & $7.26 \mathrm{E}-4$ & $1.06 \mathrm{E}-4$ & Thailand National Database \\
\hline
\end{tabular}

\section{Impact assessment}

The impact assessment evaluates three impact categories: global warming potential, acidification potential and eutrophication potential based on the inventory analysis. The potential impact assessment was quantified by using classification and characterization factors of CML baseline 2001. The calculation of environmental impacts lied on the equation 1:

$$
E_{x}=\sum_{i}\left(A_{i} \times E F_{x, i}\right)
$$

Where $\mathrm{E}_{\mathrm{x}}$ is environmental impact $\mathrm{x}$ (index for impact category: global warming, acidification, eutrophication). $A_{i}$ is the activity data in each of the cultivation process as shown in Table $1 . \mathrm{EF}_{\mathrm{x}, \mathrm{i}}$ stands for the emission factor for each impact category due to activity $i$ in the cultivation process, as shown in Table 2.

Table 3 illustrates 3 environmental impacts of $1 \mathrm{~kg}$ straw mushroom production in each case. The results reveal that case 2 is the lowest impact category compared to 
others. In case 2, the equivalence of $0.8 \mathrm{kgCO}_{2} \mathrm{e}, 8.3 \mathrm{gSO}_{2} \mathrm{e}$ and $1.9 \mathrm{kgPO}_{4}{ }^{3-} \mathrm{e}$ are emitted as a result of the production of $1 \mathrm{~kg}$ of the straw mushroom. Case 1 as the conventional cultivation process emitted global warming potential, acidification potential and eutrophication potential that are higher than case 2 at $89 \%, 426 \%$ and $63 \%$, respectively. Case 3 is the highest impact among three cases for several reasons. First, case 3 requires more raw materials such as cotton, rice bran and cow manure to produce $1 \mathrm{~kg}$ of straw mushroom. Second, case 3 uses soybean hull instead of straw when the emission factor of soybean hull is higher than that of rice straw.

Table 3. Environmental impact of the production of $1 \mathrm{~kg}$ straw mushroom

\begin{tabular}{lllll}
\hline Impact category & Unit & Case 1 & Case 2 & Case 3 \\
\hline Global warming & $\mathrm{kg} \mathrm{CO}_{2} \mathrm{e}$ & 1.5837 & 0.8372 & 5.3973 \\
Eutrophication & $\mathrm{kg} \mathrm{PO}_{4}{ }^{3-} \mathrm{e}$ & 0.0100 & 0.0019 & 0.0425 \\
Acidification & $\mathrm{kg} \mathrm{SO}_{2} \mathrm{e}$ & 0.0135 & 0.0083 & 0.0239 \\
\hline
\end{tabular}

For better understanding of these results, the breakdown of contributions to the environmental impacts are performed. Figure 1 illustrates the percentage contribution of three environmental impact categories from different cases. In case 1, the hotspot of global warming potential, acidification potential and eutrophication potential are cotton production $(42 \%)$, cotton production $(43 \%)$ and soybean hull $(72 \%)$, respectively. The main factor to global warming potential caused by cotton production is the use of plant protecting chemicals like pesticides, herbicides and synthetic fertilizers (Murugesh and Selvadass, 2013). The soybean hull and wood chip are shown to be the second and the third contributors to the global warming impact.

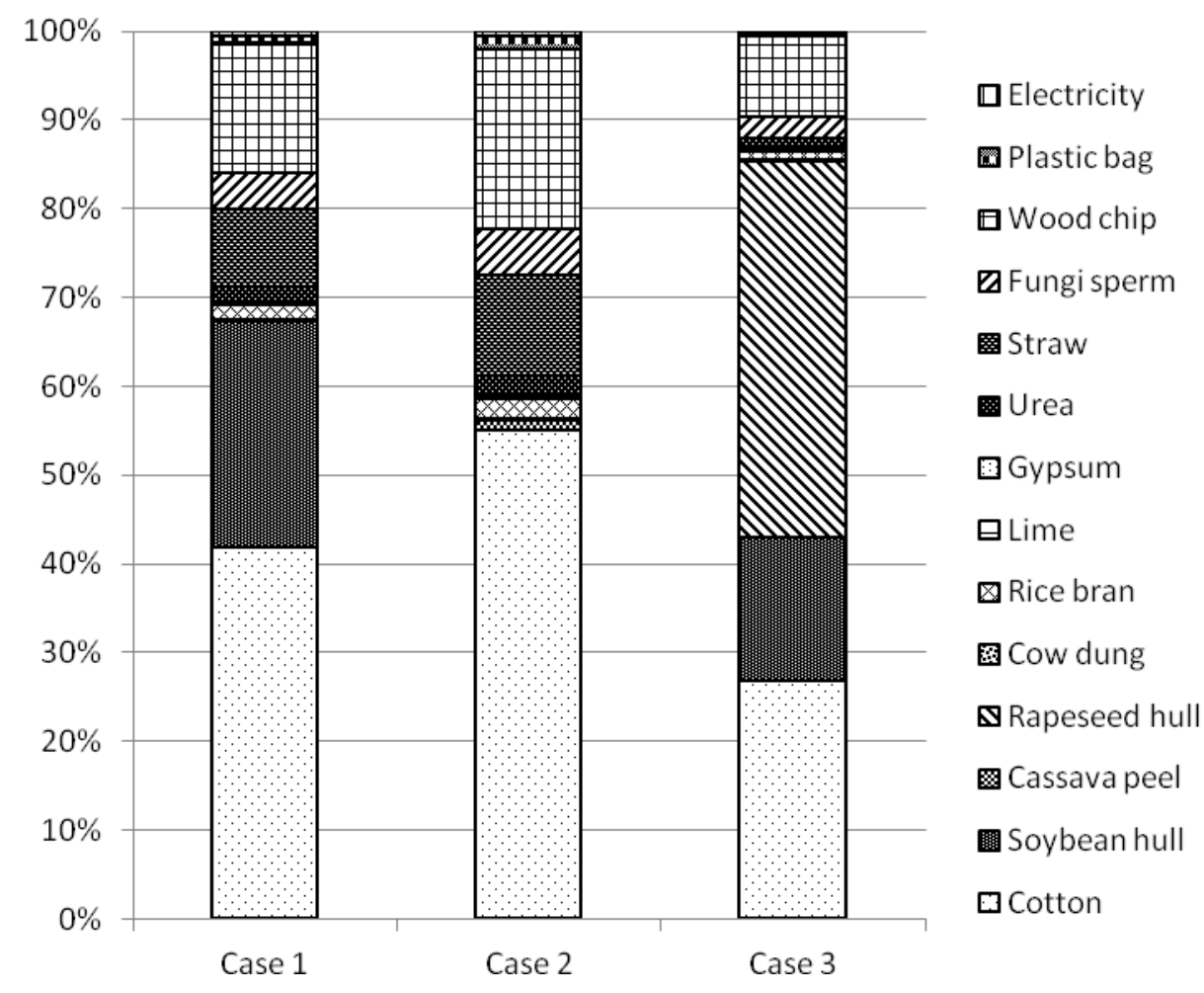

(a) Global warming contribution 


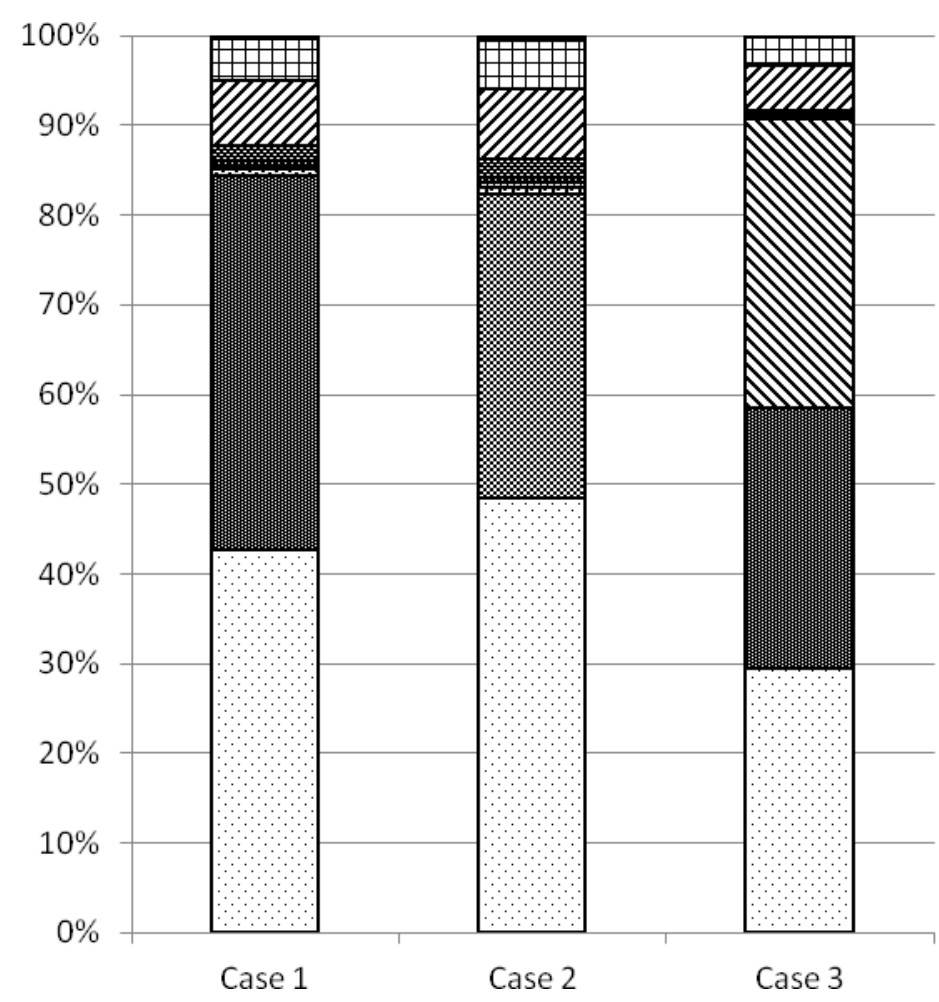

(b) Acidification contribution

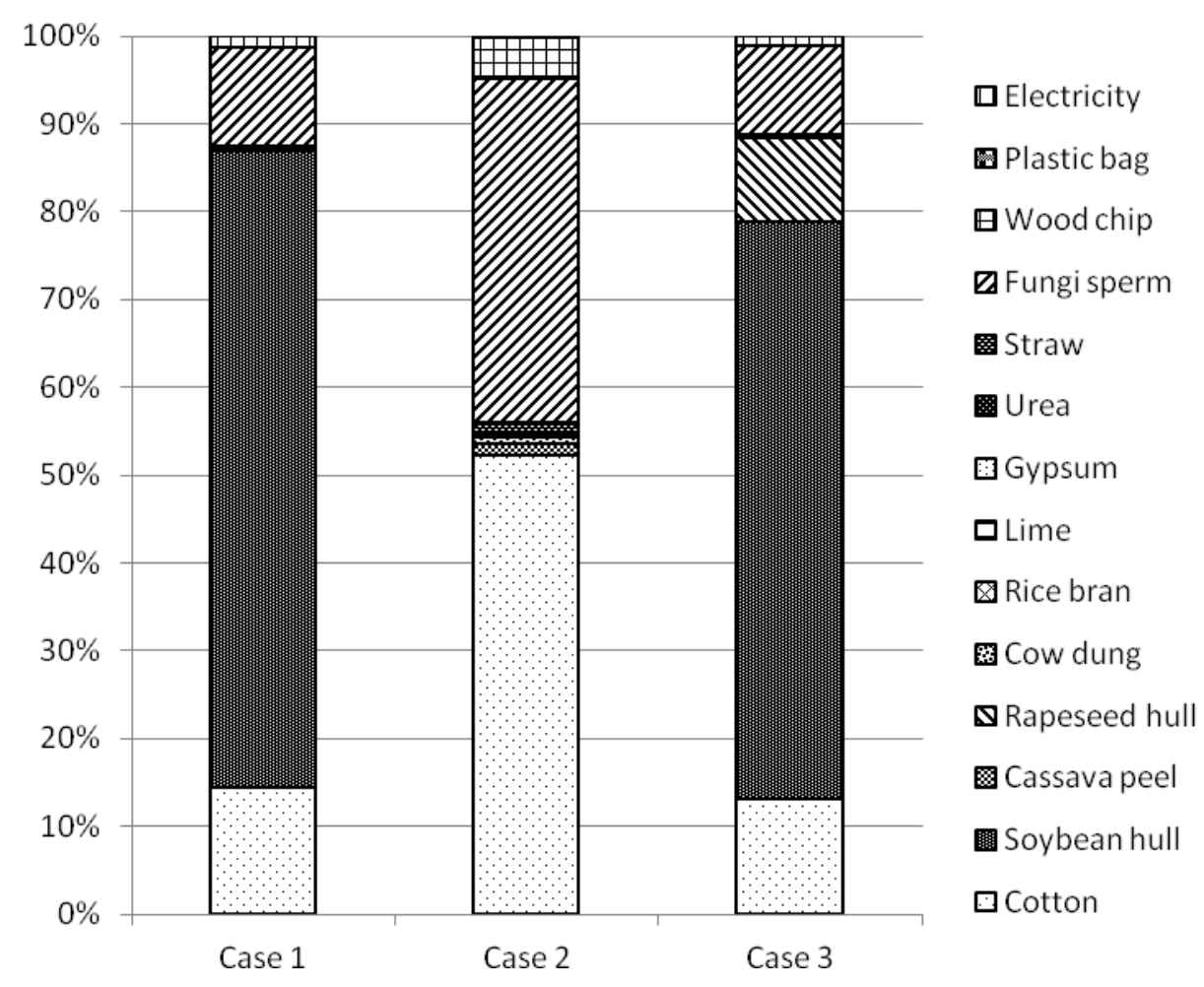

(c) Eutrophication contribution
口Electricity

OPlastic bag

由Wood chip

D Fungi sperm

圆 Straw

Urea

GGypsum

曰日Lime

$\otimes$ Rice bran

图Cow dung

$\mathbb{Q}$ Rapeseed hull

assava peel

in Soybean hull

口Cotton 
Electricity and use of fertilizers does not seem to have significant impact potentials. The contribution of electricity and fertilizers on the global warming potential are only less than $1 \%$ and $2 \%$, respectively. In case 2 , cotton production has been identified as the hotspot of all impact categories. The global warming potential, acidification potential and eutrophication potential of case 2 related to cotton production are $55 \%, 48 \%$ and $52 \%$ of total impact categories respectively. The production and combustion of wood chip and straw production are shown to be the second and the third contributors to global warming. In case 3 , the hotspot of global warming potential and acidification are rapeseed production; $42 \%$ and 32\%, respectively. However, the hotspot of eutrophication in case 3 is soybean hull (66\%). From the Figure 1, it is clear that cotton production is an important source of pollutants and their environmental impacts, followed by rapeseed hull and soybean hull production.

\section{Uncertainty analysis}

Uncertainty analysis is one of the necessary parts of the analysis model. It is used in order to test the robustness of conclusions to uncertainties in assumptions (Sterman, 2000). In this study, an uncertainty analysis was assumed to identify the effect of some possible changes on the straw mushroom cultivation. Six scenarios were considered in this uncertainty analysis: (1) straw mushroom yield has been increased by 10\%, (2) straw mushroom yield has been decreased by $10 \%$, (3) fungi spawn yield has been increased by $10 \%$, (4) fungi spawn yield has been reduced by $10 \%$, (5) cotton cultivation has been changed to organic farming (6) HDPE plastic has been switched to biodegradable plastic (Table 4). The results of this uncertainty analysis are compared to the base case.

Table 4. Variables changed in sensitivity analysis

\begin{tabular}{|c|c|c|}
\hline Variable & Base case & Assumption changed \\
\hline Straw mushroom yield & $\begin{array}{l}1 \mathrm{~kg} \text { of straw mushroom } \\
\text { (Data from Table 1) }\end{array}$ & Decrease and increase by $10 \%$ \\
\hline Fungi spawn yield & $1 \mathrm{~kg}$ of fungi spawn production & Decrease and increase by $10 \%$ \\
\hline Cotton cultivation & Synthetic fertilizer & Organic fertilizer \\
\hline HDPE plastic & HDPE & $\begin{array}{l}\text { Sugarcane-based biodegradable } \\
\text { plastic }\end{array}$ \\
\hline
\end{tabular}

As shown in Table 5, the uncertainty values ranging between $-20.02 \%$ to $11.11 \%$ have a significant impact on the final results. Based on this observation, straw mushroom yield and type of cotton cultivation posts a significant effect to environmental impact results. A $10 \%$ increase in straw mushroom yield results at the range of $8.89 \%$ to $9.09 \%$ decreases from base case, whereas a $10 \%$ decrease in straw mushroom yield results at the range $10.98 \%$ to $11.11 \%$ increases from base case. In contrast, increasing fungi spawn yield results in only $0.23 \%$ to $3.56 \%$ decreases from base case. For scenario 4, in the event that fungi spawn yield decreases to $10 \%$, this has a negative effect on the environmental impact up to $4.35 \%$. For scenario 5, if organic cotton cultivation is used to replace synthetic cotton cultivation, this has a positive effect on the environmental impact up to $20.02 \%$ of acidification potential in case 2 . For scenario 6, providing that biodegradable plastic is used to replace HDPE plastic bags, it is found that the impact results at the range of $-1.09 \%$ to $1.12 \%$ different from base 
case. Therefore, it is interesting that fungi spawn yield and types of plastic bags do not seem to have significant impacts.

Table 5. Unvertainty analysis of factors related to straw mushroom production in term of \% difference

\begin{tabular}{lccccccccc}
\hline & \multicolumn{3}{c}{ Case 1 } & \multicolumn{3}{c}{ Case 2 } & \multicolumn{3}{c}{ Case 3 } \\
\cline { 2 - 10 } & GWP & AP & EP & GWP & AP & EP & GWP & AP & EP \\
\hline Scenario1 & $-8.98 \%$ & $-9.09 \%$ & $-9.09 \%$ & $-8.89 \%$ & $-9.09 \%$ & $-9.09 \%$ & $-9.06 \%$ & $-9.09 \%$ & $-9.09 \%$ \\
Scenario2 & $10.98 \%$ & $11.11 \%$ & $11.11 \%$ & $10.86 \%$ & $11.11 \%$ & $11.11 \%$ & $11.07 \%$ & $11.11 \%$ & $11.11 \%$ \\
Scenario3 & $-0.37 \%$ & $-0.65 \%$ & $-1.01 \%$ & $-0.47 \%$ & $-0.722 \%$ & $-3.56 \%$ & $-0.23 \%$ & $-0.45 \%$ & $-0.91 \%$ \\
Scenario4 & $0.45 \%$ & $0.79 \%$ & $1.24 \%$ & $0.58 \%$ & $0.88 \%$ & $4.35 \%$ & $0.29 \%$ & $0.55 \%$ & $1.11 \%$ \\
Scenario5 & $-7.84 \%$ & $-17.60 \%$ & $-4.72 \%$ & $-10.30 \%$ & $-20.02 \%$ & $-17.05 \%$ & $-5.01 \%$ & $-12.17 \%$ & $-4.29 \%$ \\
Scenario6 & $-0.57 \%$ & $0.68 \%$ & $0.00 \%$ & $-1.09 \%$ & $1.12 \%$ & $1.49 \%$ & $-0.17 \%$ & $0.22 \%$ & $0.12 \%$ \\
\hline
\end{tabular}

The mushroom yield is a factor that varies in environmental impacts, as shown in Table 5. However, these values have no effect to evaluate in percentage in terms of contributions as shown in Table 5 that results of scenario 1-4 are at the same percentile. From Table 5 and Table 6, it is obvious that cotton production is an important source of environmental impacts. In case 1 , cotton production has the largest share in global warming (42\%), acidification (43\%) and eutrophication (14\%). In case 2, cotton production also has the largest share in global warming (55\%), acidification (48\%) and eutrophication (52\%). In case 3, rapeseed hull has the largest share in global warming $(42 \%)$, acidification (32\%) and eutrophication (10\%).

Table 6. Percent contribution of environmental impacts of scenario 1-4

\begin{tabular}{lccccccccc}
\hline & \multicolumn{3}{c}{ Case 1 } & \multicolumn{3}{c}{ Case 2 } & \multicolumn{3}{c}{ Case 3 } \\
\cline { 2 - 10 } & GWP & AP & EP & GWP & AP & EP & GWP & AP & EP \\
\hline Cotton & $42 \%$ & $43 \%$ & $14 \%$ & $55 \%$ & $48 \%$ & $52 \%$ & $27 \%$ & $29 \%$ & $13 \%$ \\
Soybean hull & $25 \%$ & $42 \%$ & $72 \%$ & $0 \%$ & $0 \%$ & $0 \%$ & $16 \%$ & $29 \%$ & $66 \%$ \\
Cassava peel & $0 \%$ & $0 \%$ & $0 \%$ & $1 \%$ & $34 \%$ & $1 \%$ & $0 \%$ & $0 \%$ & $0 \%$ \\
Rapeseed hull & $0 \%$ & $0 \%$ & $0 \%$ & $0 \%$ & $0 \%$ & $0 \%$ & $42 \%$ & $32 \%$ & $10 \%$ \\
Cow dung & $2 \%$ & $1 \%$ & $0 \%$ & $0 \%$ & $1 \%$ & $1 \%$ & $0 \%$ & $0 \%$ & $0 \%$ \\
Rice bran & $0 \%$ & $0 \%$ & $0 \%$ & $2 \%$ & $0 \%$ & $0 \%$ & $1 \%$ & $0 \%$ & $0 \%$ \\
Lime & $0 \%$ & $0 \%$ & $0 \%$ & $0 \%$ & $0 \%$ & $0 \%$ & $0 \%$ & $0 \%$ & $0 \%$ \\
Gypsum & $2 \%$ & $0 \%$ & $0 \%$ & $0 \%$ & $0 \%$ & $0 \%$ & $0 \%$ & $0 \%$ & $0 \%$ \\
Urea & $10 \%$ & $1 \%$ & $0 \%$ & $3 \%$ & $1 \%$ & $0 \%$ & $1 \%$ & $0 \%$ & $0 \%$ \\
Straw & $4 \%$ & $2 \%$ & $0 \%$ & $11 \%$ & $2 \%$ & $1 \%$ & $0 \%$ & $0 \%$ & $0 \%$ \\
Fungi spawn & $15 \%$ & $7 \%$ & $11 \%$ & $5 \%$ & $8 \%$ & $39 \%$ & $3 \%$ & $5 \%$ & $10 \%$ \\
Wood chip & $1 \%$ & $5 \%$ & $1 \%$ & $20 \%$ & $5 \%$ & $5 \%$ & $9 \%$ & $3 \%$ & $1 \%$ \\
Plastic bag & $0 \%$ & $0 \%$ & $0 \%$ & $1 \%$ & $1 \%$ & $0 \%$ & $0 \%$ & $0 \%$ & $0 \%$ \\
Electricity & $0 \%$ & $0 \%$ & $0 \%$ & $1 \%$ & $0 \%$ & $0 \%$ & $0 \%$ & $0 \%$ & $0 \%$ \\
\hline
\end{tabular}

The cotton used in this investigation has global warming potential in case 1, case 2 and case 3 of $0.66 \mathrm{kgCO}_{2} \mathrm{e}$ per $\mathrm{kg}$ of straw mushroom, $0.46 \mathrm{kgCO}_{2} \mathrm{e}$ per $\mathrm{kg}$ of straw mushroom and $1.44 \mathrm{kgCO}_{2} \mathrm{e}$ per $\mathrm{kg}$ of straw mushroom respectively. As mentioned 
earlier, cotton production is a quantitatively important factor that contribute to global warming potential with $42 \%$ in case $1,55 \%$ in case 2 and $27 \%$ in case 3 . The synthetic cotton cultivation had a global warming potential of $1.33 \mathrm{kgCO}_{2} \mathrm{e}$ per $\mathrm{kg}$ of cotton, acidification potential of $1.16 \mathrm{E}-2 \mathrm{kgSO}_{2} \mathrm{e}$ per $\mathrm{kg}$ of cotton and $2.89 \mathrm{E}-3 \mathrm{kgPO}_{4}{ }^{3-} \mathrm{e}$ per $\mathrm{kg}$ of cotton (Murugesh and Selvadass, 2013). However, based on Murugesh and Selvadass (2013) if organic cotton were used instead, the global warming potential, acidification potential and eutrophication potential would be reduced by $19 \%, 41 \%$ and $33 \%$ respectively. Therefore, the contribution of environmental impact due to the change of cotton cultivation is demonstrated in Table 7. It is found that the change in cotton cultivation seems to have a significant influence to all impacts. The contribution of cotton cultivation to global warming potential of case 1, case 2 and case 3 are 37\%, $50 \%$ and $23 \%$ respectively.

Table 7. Percent contribution of environmental impacts of scenario 5

\begin{tabular}{lccccccccc}
\hline & \multicolumn{3}{c}{ Case 1 } & \multicolumn{3}{c}{ Case 2 } & \multicolumn{3}{c}{ Case 3 } \\
\cline { 2 - 10 } & GWP & AP & EP & GWP & AP & EP & GWP & AP & EP \\
\hline Cotton & $37 \%$ & $30 \%$ & $10 \%$ & $50 \%$ & $36 \%$ & $42 \%$ & $23 \%$ & $20 \%$ & $9 \%$ \\
Soybean hull & $28 \%$ & $51 \%$ & $76 \%$ & $0 \%$ & $0 \%$ & $0 \%$ & $17 \%$ & $33 \%$ & $69 \%$ \\
Cassava peel & $0 \%$ & $0 \%$ & $0 \%$ & $1 \%$ & $42 \%$ & $2 \%$ & $0 \%$ & $0 \%$ & $0 \%$ \\
Rapeseed hull & $0 \%$ & $0 \%$ & $0 \%$ & $0 \%$ & $0 \%$ & $0 \%$ & $45 \%$ & $37 \%$ & $10 \%$ \\
Cow dung & $0 \%$ & $1 \%$ & $0 \%$ & $0 \%$ & $1 \%$ & $1 \%$ & $0 \%$ & $1 \%$ & $0 \%$ \\
Rice bran & $2 \%$ & $0 \%$ & $0 \%$ & $2 \%$ & $0 \%$ & $0 \%$ & $1 \%$ & $0 \%$ & $0 \%$ \\
Lime & $0 \%$ & $0 \%$ & $0 \%$ & $0 \%$ & $0 \%$ & $0 \%$ & $0 \%$ & $0 \%$ & $0 \%$ \\
Gypsum & $0 \%$ & $0 \%$ & $0 \%$ & $0 \%$ & $0 \%$ & $0 \%$ & $0 \%$ & $0 \%$ & $0 \%$ \\
Urea & $3 \%$ & $1 \%$ & $0 \%$ & $3 \%$ & $1 \%$ & $1 \%$ & $1 \%$ & $0 \%$ & $0 \%$ \\
Straw & $9 \%$ & $2 \%$ & $0 \%$ & $13 \%$ & $3 \%$ & $1 \%$ & $0 \%$ & $0 \%$ & $0 \%$ \\
Fungi spawn & $4 \%$ & $9 \%$ & $12 \%$ & $6 \%$ & $10 \%$ & $47 \%$ & $3 \%$ & $6 \%$ & $10 \%$ \\
Wood chip & $16 \%$ & $6 \%$ & $1 \%$ & $23 \%$ & $7 \%$ & $6 \%$ & $10 \%$ & $4 \%$ & $1 \%$ \\
Plastic bag & $1 \%$ & $0 \%$ & $0 \%$ & $2 \%$ & $1 \%$ & $0 \%$ & $0 \%$ & $0 \%$ & $0 \%$ \\
Electricity & $1 \%$ & $0 \%$ & $0 \%$ & $1 \%$ & $0 \%$ & $0 \%$ & $0 \%$ & $0 \%$ & $0 \%$ \\
\hline
\end{tabular}

The HDPE plastic bag used in this investigation has a global warming potential of $1.92 \mathrm{kgCO}_{2} \mathrm{e}$ per kg HDPE, an acidification potential of $6.57 \mathrm{E}-3 \mathrm{kgSO}_{2} \mathrm{e}$ per $\mathrm{kg} \mathrm{HDPE}$ and an eutrophication potential of 5.16E-4 $\mathrm{kgPO}_{4}{ }^{3-} \mathrm{e}$ per $\mathrm{kg}$ HDPE. If sugarcane based biodegradable plastic were used instead, the environmental impacts would descent to $0.5 \mathrm{kgCO}_{2} \mathrm{e}$ per $\mathrm{kg}$ bioplastic for global warming potential, $0.021 \mathrm{kgSO}_{2} \mathrm{e}$ per $\mathrm{kg}$ bioplastic for acidification potential and 5.00E-3 $\mathrm{kgPO}_{4}{ }^{3-} \mathrm{e}$ per $\mathrm{kg}$ bioplastic (Groot and Boren, 2010). Different contributors to the global warming potential, acidification potential and eutrophication potential are shown in Table 7. It was found that the change in the petroleum based plastic to biodegradable plastic caused reduction in global warming potential up to $1.09 \%$ of base case but increase in both acidification potential and eutrophication potential up to $1.49 \%$ of base case, as shown in Table 5. From Table 8 , biodegradable plastic contributed from range $0 \%$ to $2 \%$ of total impacts. This means the change of plastic does not seem to have any significant influence among the three impacts. 
Table 8. Percent contribution of environmental impacts of scenario 6

\begin{tabular}{lccccccccc}
\hline & \multicolumn{3}{c}{ Case 1 } & \multicolumn{3}{c}{ Case 2 } & \multicolumn{3}{c}{ Case 3 } \\
\cline { 2 - 11 } & GWP & AP & EP & GWP & AP & EP & GWP & AP & EP \\
\hline Cotton & $42 \%$ & $42 \%$ & $14 \%$ & $56 \%$ & $48 \%$ & $51 \%$ & $27 \%$ & $29 \%$ & $13 \%$ \\
Soybean hull & $26 \%$ & $42 \%$ & $72 \%$ & $0 \%$ & $0 \%$ & $0 \%$ & $16 \%$ & $29 \%$ & $66 \%$ \\
Cassava peel & $0 \%$ & $0 \%$ & $0 \%$ & $1 \%$ & $34 \%$ & $1 \%$ & $0 \%$ & $0 \%$ & $0 \%$ \\
Rapeseed hull & $0 \%$ & $0 \%$ & $0 \%$ & $0 \%$ & $0 \%$ & $0 \%$ & $42 \%$ & $32 \%$ & $10 \%$ \\
Cow dung & $0 \%$ & $1 \%$ & $0 \%$ & $0 \%$ & $1 \%$ & $1 \%$ & $0 \%$ & $0 \%$ & $0 \%$ \\
Rice bran & $2 \%$ & $0 \%$ & $0 \%$ & $2 \%$ & $0 \%$ & $0 \%$ & $1 \%$ & $0 \%$ & $0 \%$ \\
Lime & $0 \%$ & $0 \%$ & $0 \%$ & $0 \%$ & $0 \%$ & $0 \%$ & $0 \%$ & $0 \%$ & $0 \%$ \\
Gypsum & $0 \%$ & $0 \%$ & $0 \%$ & $0 \%$ & $0 \%$ & $0 \%$ & $0 \%$ & $0 \%$ & $0 \%$ \\
Urea & $3 \%$ & $0 \%$ & $0 \%$ & $3 \%$ & $1 \%$ & $0 \%$ & $2 \%$ & $0 \%$ & $0 \%$ \\
Straw & $9 \%$ & $2 \%$ & $0 \%$ & $11 \%$ & $2 \%$ & $1 \%$ & $0 \%$ & $0 \%$ & $0 \%$ \\
Fungi spawn & $4 \%$ & $7 \%$ & $11 \%$ & $5 \%$ & $8 \%$ & $39 \%$ & $3 \%$ & $5 \%$ & $10 \%$ \\
Wood chip & $15 \%$ & $5 \%$ & $1 \%$ & $20 \%$ & $5 \%$ & $5 \%$ & $8 \%$ & $3 \%$ & $1 \%$ \\
Plastic bag & $0 \%$ & $1 \%$ & $0 \%$ & $0 \%$ & $2 \%$ & $2 \%$ & $0 \%$ & $0 \%$ & $0 \%$ \\
Electricity & $0 \%$ & $0 \%$ & $0 \%$ & $1 \%$ & $0 \%$ & $0 \%$ & $0 \%$ & $0 \%$ & $0 \%$ \\
\hline
\end{tabular}

\section{Conclusion}

Overall, the study has shown that the three environmental impacts namely; global warming potential, acidification potential and eutrophication potential of $1 \mathrm{~kg}$ of mushroom cultivation in Thailand for the best case that used the cassava formula were estimated using the LCA methodology to be $0.84 \mathrm{kgCO}_{2} \mathrm{e}, 8.3 \mathrm{gSO}_{2} \mathrm{e}$ and $1.9 \mathrm{gPO}_{4}{ }^{3-} \mathrm{e}$, respectively. The hotspot was identified to be the production of cotton which accounts for $48 \%$ to $55 \%$ of total effects among three environmental impact categories. In the best case, electricity and fertilizers, however, played a negligible role. Moreover, it was observed that the results varied according to the production yield and types of cotton cultivation. The production yield increased or decreased by $10 \%$ affected environmental impacts by $-9.09 \%$ to $11.11 \%$ compared to the base case. Organic cotton cultivation is highly recommended as environmental impacts could be reduced up to $20.02 \%$ of acidification impact compared to the base case. This study has also exhibited that raw materials such as cotton, soybean hull, cassava peel and rapeseed hull are the main impacts in the life cycle of straw mushroom production.

\section{REFERENCES}

[1] Akhtar, S., Shakeel, S., Mehmood, A., Hamid, A. and Saif, S. (2013): Comparative analysis of animal manure for soil conditioning. - Int. J. of Agronomy and Plant Production 4(12): 3360-3365.

[2] Anon (1983): Growing mushrooms, Cultivation of Volvariella volvacea: 56-63.

[3] Chang, S.T., Milles, P.G. (1991): Recent trends in wood production of edible mushrooms. - The Mushroom Journal 503: 15-18.

[4] FAOSTAT (2012): Food and agriculture organization of the United Nations. Acessed April 2015: http://faostat.fao.org.

[5] Groot, W.J. and Boren, T. (2010): Life cycle assessment of the manufacture of lactide and PLA biopolymers from sugarcane in Thailand. - Int. J. of Life cycle assessment 15: 970984. 
[6] Gunady, M.G.A., Biswas, W., Solah, V.A., James, A.P. (2012): Evaluating the global warming potential of the fresh produce supply chain for strawberries, romaine/cos lettuces (Lactuca sativa) and button mushrooms (Agaricu bisporus) in Western Australia using life cycle assessment (LCA). - J. of Cleaner Production 28: 81-87.

[7] IPCC (2006): IPCC Guidelines for National Greenhouse Gas Inventories.- IGES, Japan.

[8] ISO14040 (2006): International Standard Organization, ISO14040:2006 Environmental Management-Life Cycle Assessment-Principles and Framework, Geneva, Switzerland.

[9] Kasmaprapruet, S., Paengjuntuek, W., Saikhwan, P., Phungrassami, H. (2009): Life cycle assessment of milled rice production: case study in Thailand. - European J. of Scientific Research 30(2): 195-203.

[10] Kwon, H. and Thatithatgoon, S. (2004): Mushroom growing in northern Thailand. - In: Gush, R. (ed.) Mushroom gowers' handbook 1: oyster mushroom cultuivation. Seoul: MushWorld-Heineart Inc.

[11] Murugesh, B.K. and Selvadass, M. (2013): Life cycle assessment for cultivation of conventional and organic seed cotton fibres. - Int. J. of Research in Environmental Science and Technology 3(1): 39-45.

[12] OAE (2013): Office of Agricultural Economics, Ministry of Agriculture and Cooperatives, Thailand. Acessed September 2014: http://www.oae.go.th.

[13] Oei, P. (2005): Small-scale mushroom cultivation-oyster, shiitake and wood ear mushrooms. - In: Feijter, J. (ed) Agromisa Foundation and CTA, Netherlands.

[14] Rajapakse, P. (2011): New cultivation techonology for paddy straw mushroom (Volcariella volvacea). - Proceddings of the $7^{\text {th }}$ International Conference on Mushroom Biology and Mushroom Products, France.

[15] Romaine, C.P., Marlowe, A. (1995): - Intact seed-based delayed-released nutrient supplement for mushroom cultivation, US 5427592A.

[16] Sterman, J.D. (2000): Business dynamics: Systems thinking and modeling for a complex world. - In: Irwin (ed.), McGraw-Hill, Newyork.

[17] Tharun, G. (1993): Promotion of mushroom production and bioconversion of wastes for income generation in rural areas, CDG 3EAPO's Biotechnology Training Project. - In: Chang, S.T., Bussivell, J.A. Chril, S. (eds.) Mushroom Biology and Mushroom products, Hong Kong Chinese Univesity Press.

[18] Thongnaitham, M. (2012): Organic mushroom cultuvation manual, FREELAND Foundation.

[19] Ueawiwatsakul, S., Mungcharoen, T., Tongpool, R. (2014): Life cycle assessment of Sajor-caju mushroom (Pleurotus Sjor-caju) from difference sizes of farms in Thailand. Int. J. of Environmental Science and Development 5(5): 435-439. 